\title{
XIV. On the sources of Nile; being an attempt to assign the limits of the basin of that river
}

\section{Charles T. Beke Esq. Ph.D. F.S.A.}

To cite this article: Charles T. Beke Esq. Ph.D. F.S.A. (1849) XIV. On the sources of Nile; being an attempt to assign the limits of the basin of that river , Philosophical Magazine, 35:234, 98-114, DOI: $10.1080 / 14786444908646317$

To link to this article: http://dx.doi.org/10.1080/14786444908646317

$$
\text { 曲 Published online: } 30 \text { Apr } 2009 .
$$

5 Submit your article to this journal $\square$

Џll Article views: 3

Q View related articles 두 
of the siphon is stopped, the water in the tube $b$ remaining at just sufficient height to exclude the air from the interior of the reservoir.

This simple apparatus may be affixed to any convenient vessel having an aperture at the bottom; all other openings being of course closed, so as to prevent the ingress of air except by the tube $b$. A common salt glaze earthenware washing-bottle, or a Griffin's gas-holder, will be found to answer the purpose perfectly.

Glasgow College Laboratory, July 6, 1849 .

XIV. On the Sources of the Nile; being an attempt to assign the limits of the Basin of that River. By CHARLES T. BeкE, Esq., Ph.D., F.S.A. \&i.*

I $\mathrm{N}$ treating of the sources of the Nile, it is not intended to regard any particular source or spring as being more especially and exclusively the true head of that river. It will not even be discussed whether this or that large branch of the river should be considered to be the principal one. Such questions at the outset are not likely to lead to any satisfactory result. Our object must be in the first place to determine the entire limits of the basin of the river; we have next to ascertain what principal arms unite to form the main stream; we must then trace to their heads the several smaller streams which form those branches; and when we have succeeded in all these points, we shall then-but not before-be competent to decide which of these numerous ramifications has the fairest claim to be regarded as the true source of the Nile.

It may however be objected, and not without a show of reason, that though this is the theoretical method of investigating the subject, yet the question is susceptible of a more practical solution;-that, as in the case of most other rivers, there is some particular stream which by common consent is looked on as the source of the Nile, and this without regard to its being actually the head of the longest or the largest branch. Were this really the case, we should in one sense be bound to acquiesce in the recognition of such a source, even though it might not possess all the attributes of the true head of the river. But the fact is not so. The Abái, the river of Abessinia, whose source was visited and described by the Portuguese Jesuits in the beginning of the seventeenth

* Communicated by the Syro-Egyptian Society of London, having been read before that Society on the 9th of January 1849. 
century, and 150 years later by Bruce, is (as I know from personal experience) undoubtedly considered by the modern Abessinians to be the Nile. But among the ancient Abessinians, (or more properly speaking the Axomites of Northern Abessinia, who were known to the civilized world in the first ages of the Christian æra,) it was the Tákkazie, and not the Abái, which was regarded as the Nile. Of this a direct proof is given in the second Adulitic inscription, which, recording the victories of one of the princes of that country, says:"After this, I reduced Ava and Tzíamo, Gambêla and the country round it, Zingabênè, Angabè, Tíama, and the $A^{\prime}$ thagai, Kálaa, and Semênè, a nation beyond the Nile, among mountains difficult of access and covered with snow; in all this region there is hail and frost, and snow so deep that the troops sunk up to their knees. I passed the river, and subdued them:"-in which passage it is manifest that reference is made to the well-known province of Sámien beyond the Tákkazie, in which province are the loftiest mountaius of Abessinia topped with snow, or more properly speaking, a light kind of hail*. It is not unimportant to the present question to remark that in the ancient Ethiopic language, the word Tákkazie is not a proper name, but an appellative signifying river in general; so that "the Ták kazie" is sinıly "the river;" and it is in this sense that in the Ethiopic Scrip. tures it is said that the waters of the Táklkazie were curned by Moses into blood.

But the question of superiority is far from lying between these two rivers, the Tạkkazie and Abái, alone. Proceeding further southwards up the direct stream of the Bahr el Abyad or White River, we come, in about $9^{\circ} \mathrm{N}$. lat., to another large arm named Sobát, Telfi, or River of Habesh, which in its upper course is called Bako, then Uma, and afterwards Gódjeb. The source of the Gódjeb is in $\mathrm{Kaffa}$, where it is revered by the natives as the head of the Nile. Nevertheless there is no more real ground for such a preference of the Gódjeb than there exists in the case of the two other rivers already mentioned. The recent expeditions sent by Mohammed Ali, Pasha of Egypt, to explore the Nile, have ascended the White River

* "Snow is very rare in Abessinia; it is seen on days when the clouds are but little raised above the earth, and are at the same time widely extended. The flakes are small, triangular, and radiated.

"Hailstones which fall at an altitude of 4650 to 4700 mètres $[15,500$ to 15,600 English feet] have the form of a truncated polyedric pyramid, hollowThe edges of the pyramid are granulated. This hail is almost as light as ed at the base and summit; the hollow being in the form of a reversed cone. snow."-Letter from M. Schimper, on the Meteorology of Abessinia, in the Comptes Rendus, vol. xxvi. No. 7. (Feh. 14, 1848), p. 229 . 
as far as the country of Bari in $4^{\circ} \mathrm{N}$, lat., 500 miles above the confluence of the Sobát or River of Habesh; and still the head of the Nile is there said to be distant a month's journey further to the south.

In the absence, then, of unanimity among the people of the countries watered by the several branches of the Nile, who each regard, not unnaturally, their own particular river as the principal stream; it is manifest that the question is an open one, and that its solution must be attempted on general and scientific principles.

When we trace the course of a river, from its mouth upwards, to the furthest extremity of each of its several tributaries, we arrive ultinately at a point where the waters no longer flow towards that river, but take their course in the opposite direction. This is called in Latin divortia aquarum-the parting (or flowing in contrary directions) of the waters-and in German die Wasserscheide, which means the same. English geographers have of late years adopted, through the geologists, the expression watershed, which is evidently a mere corruption of the German Wasserscheide, and was probably first brought into use among us by miners from Germany. But such an expression is objectionable; as to the mere English scholar it would seem to be a native compound of the words water and shed, and hence might give rise to the idea of a river's basin being intended rather than the division between two adjoining basins. The word waterparting is far preferable. For it is a literal English translation of the Latin divortia aquarum and of the German Wasserscheide; it expresses the true sense, and it is not susceptible of ambiguity.

The waterparting between the basins of two rivers is not necessarily coincirfent with a mountain-chain, or identical with it. On the contrary, we have instances of a river's passing through a mountain-chain, and taking its rise in an extensive elevated plain, so level in appearance as to render it difficult, at first sight, to determine in which direction the waters flow, or ought to flow. But though the waterparting may not be identical with an abnormal elevation, such as a mountain-chain, it must, in the nature of things, be the greatest normal elevation: it must be that point-or rather that line or series of points - at which the waters from the heavens, no longer continuing to find a passage in the one direction, seek it in another. Thus the waterparting forms the extreme limits of the basin of a river, and the boundary-line between the several distinct hydrographical systems of which a continent is composed.

The sources of the Nile, then, are all those head-streams 
which rise along the extreme limits of the basin of that river, at the waterparting between it and the conterminous basins of other African rivers flowing towards the Red Sea, the Indian Ocean, the Atlantic and the Mediterranean respectively, or possessing (as is the case with sume rivers of Asia and America, and even of Africa) separate inland hydrographical systems unconnected with the ocean. It is in this sense that I propose to treat of the sources of the Nile.

Commencing at the isthmus of Suéz, and proceeding southwards to about the 16 th parallel of north latitude, we find a tract of desert country lying between the Nile and the Red Sea, and presenting no point of very great elevation. As, however, we approach the parallel of $16^{\circ} \mathrm{N}$. lat., the land rises considerably, and forms the plateau or table-land of Abessinia. It is only of late years that the true character of this elevated region has been determined. Formerly it was generally considered that Abessinia consisted of a succession of terraces rising one above the other, the lowest being toward the Red Sea and the highest being in Enarea, where the waterparting between the Nile and the rivers having their courses towards the Indian Ocean was supposed to exist. Recent explurations have, however, determined that this opinion is erroneous. Instead of the country's rising in terraces as it recedes from the coast, its summit or culminating line is toward the coast itself, whence the land falls gralually towards the interior. This is best shown in the two sections of Abessinia, the one being from north to south and the other from east to west, published in the fourteenth volume of the Journal of the Royal Geographical Society of London.

In the beginning of the year 184.1 I explored the waterparting from Ankobanar, the capital of Shoa, northwards about forty miles, as far as Gedem; and in the printed account of this excursion* 1 remarked, that "as the longitude of the waterparting in that direction [about $40^{\circ} \mathrm{E}$. long.] corresponds very nearly with that of the waterparting in Northern Abessinia, it may perhaps be not unreasonable to infer that they are both formed by a continuation of the same central high land." This was before I was aware of the results of Dr. Rüppell's labours, and before I had carried my own series of levels further across the country to the west of Ankobar. The comparison of these has not only proved the correctness of my surmise, but, combined with the personal explorations of Dr. Krapf and M. Lefebure along the waterparting between Shoa and Tigre, and with what we know, though only more indefinitely, of its continuation to the south of Abessinia, it

* Journal of the Royal Geographical Society, vol. xii. p. 99. 
enables us to arrive at tolerably satisfactory conclusions respecting the general character of the table-land of Eastern Africa.

As a whole, this table-land may be described as a succession of undulating plains, declining very gradually towards the west and north-west, irregularly studded with loftier mountainmasses, and intersected by numerous streams; which streams, after a short course on the level of the plateau, fall abruptly into deep-cut valleys, in which they soon attain a depression of from 3000 to 4000 feet below the general level of the table-land. The valleys of the larger streams, though at first mere fissures in the rocks, soon open to a considerable width : that of the Abai, in the south of the peninsula of Godjam, is at least twenty-five miles from the extreme points where it breaks from the table-land on either side. And, as the country within these valleys is exceedingly wild and irregular, possessing all the characters of a mountainous one; nothing is easier for a traveller, who has not first taken a comprehensive view of the entire region, and who, on crossing a river, finds himself shut up within a mass of broken country rising around him on all sides to a relative elevation of 3000 or 4000 feet, or even more, -than to suppose that, in ascending this broken country on either side, he is crossing a mountain-chain; whereas, on reaching the summit, he has merely arrived on the level of the table-land.

The fall of the rivers within their deep-cut valleys diminishes gradually as they flow north-westwards to join the main stream of the Nile; which latter, skirting the western flank of the high land, is the sink into which the Tákkazie, the Bahr el Azrek or Blue River, the Godjeb, Sobát or River of Habesh, the Shoaberri, and whatever other rivers there may be, are received; its current being very sluggish, and almost stagnant in the upper part of its course, except during the floods. In the dry season its bed would indeed almost seem to consist of a succession of lakes and swamps, rather than to be the channel of a running stream. At Khartúm, at the confluence of the Blue River with the Nile, the bed of the united stream is only 1525 feet above the ocean; and it is far from improbable that even as high up as the 5th parallel of $\mathrm{N}$. latitude its absolute elevation does not much exceed 2000 feet.

On the seaward or eastern side of the waterparting, the declivity being much more abrupt and the extent of country much more limited than on the western side, the rivers must necessarily be of secondary importance. Thus, proceeding from the north, we do not meet with a stream deserving of name till we come to the Hawásh; and even this river is, near 
Aussa, lost in lake Abhébbad before reaching the ocean. The Doho, Wábbi, or Hailues's River, which is the next in succession, appears in like manner not to have sufficient water to reach the sea; at least not at all times of the year. Further to the south, we find the Wábbi-Giwéyna, or Gowín, or Juba River, possessing a substantive character as an ocean stream; but this river, during the dry season, has at its mouth a depth of only two feet. At a short distance to the south of the Equator is the Ozi or Maro, which river, though said to be of great extent, has very little water at the entrance. A short distance to the south of the Ozi is the Sabáki, which enters the sea near Melindah, and has a breadth of sixty yards at its mouth; but inland it is said to be very much larger. Yet further to the south, in about $8^{\circ} \mathrm{S}$. lat., we find the Lufidgi, a considerable river, of which the $\mathrm{Kwavi}$, in about $9^{\circ} \mathrm{S}$. lat., appears to be one of the mouths; and beyond this, in between $10^{\circ}$ and $11^{\circ} \mathrm{S}$. lat., is the Livúma, also a large stream.

These rivers of the coast have been enumerated for three reasons:-1 st. They all of them-as far at least as the Lufídgi - diminish very considerably in size as they approach the sea; which is a proof that they have not a sufficient supply of water to keep their channels open during the dry season: from which it also follows that the area of their respective basins cannot be very large. 2nd. They are all said to rise in the mountains of Abessinia; an expression which must be explained as meaning, not merely the "Abessinia" of Europeans, but the entire elevated land of Eastern Africa, which is known to the Arabs by the name of Habesh, and to the people of Senuár by that of Makádah. And thirdly, all these rivers are stated to communicate either with the Nile, or with the great lake called Nyassi, said to exist in the interior. This last statement, if not explained, might lead into error; and there is no doubt that a similar assertion with respect to other rivers of Africa-especially as regards the alleged union of the Niger with the Nile-has been the cause of much confusion and misunderstanding in the hydrography of that continent. Whatever may be the meaning attached to such an expression among Europeans, in the native phraseology of Africans it is merely the enunciation of the fact, that the several sources of these rivers of the coast are at the waterparting between their basins and those of the Nile and the streams draining into Nyassi; the contiguity of the respective sources being, according to the native mode of thinking, equivalent to an actual water-communication between the streams themselves.

To some persons it may hardly seem possible that such a mistake should occur. I will therefore give an example from 
my own personal experience. In August 184.2, when at the town of Yaush in Godjam, I obtained a good deal of valuable information respecting the countries lying to the east of the Abái and to the north of Shoa, from an intelligent Christian Abessinian merchant named Négaderas* Fanta, who traded between the market of Baso in Godjam and those of Warrahémano and Warrakallu in Eastern Abessinia.

On my inquiring of Fanta as to the course of the Milli and Berkonna, two rivers of Eastern Abessinia both tributary to the Hawásh, he answered that he knew them well, and that they joined the Abái. As I was well-aware that this was not and could not be the case, I began to fear that all the other information with which my friend had been supplying me might be of a similar character. But a little explanation showed me that he was quite right-that is to say, according to his oron way of thinking and speaking. On my expressing myself doultingly as to the correctness of his assertion, he at once appealed to myself as an eye-witness of the fact. "Do you not say (asked he) that you came to Shoa by the way of the Adál country?" I admitted that I did. " Consequently you crossed the Hawásh, into which river the Milli and Berkonna flow." This, too, I could not deny. "The Hawásh, after passing between Adál and Shoa, runs round to the south of the latter country, between it and Gurágie. Does it not ?"' As I now began to conceive Fanta's meaning, I did not think it worth while to dispute the correctness of this assertion; though $I$ knew the fact to be that the course of the river in question is from and not to the south. "Well, then, the Hawásh joins the Muger, the confluence of which river with the Abai you have seen with your own eyes, if I mistake not." This last was true enough. And so the good man, Fanta, by merely making the Hawash run the wrong way, and regarding the Muger as the continuation of it, because the two rivers have some of their sources in close contiguity on Mount Salála, succeeded in demonstrating, to his own if not to my entire satisfaction, that the Milli joins the Abai! The alleged communication between the $\mathrm{K}$ wara or Niger and the Nile, is doubtless to be understood in a similar manner; the sources of the eastern arm of the former and those of the western arm of the latter being at the waterparting between the respective basins of the two rivers, and thus "communicating with one another," according to the ordinary African phraseology.

* Négaderas means literally the head(ras) of the merchants (negade), equivalent perhaps in its primary application and value to the Console de' Mercanti of the Levant-whence our modern title of consul is derived. But it is now given as a complimentary appellation to most traders of standing. 
How far the high table-land of Eastern Africa extends southwards it is impossible to determine in the existing imperfect state of our knowledge on the subject. But it would seem that we may safely trace its continuation beyond the Equator. The country of Mono-Moézi, which lies to the south of $2^{\circ} \mathrm{S}$. lat., is described as an elevated plain, the ascent to which lies chiefly in the territories of the M'sagáara and Woháha tribes occupying the low lands to the north-west of Zanzibar, which elevated plain may be regarded as a continuation of the A bessinian plateau. And, indeed, what knowledge we possess of the geography of Southern Africa leads to the inference that the same high land extends along the entire eastern side of the Continent as far as its southern extremity; its higher eastern edge and waterparting being distant from the Indian Ocean much less than from the South Atlantic, whereby the rivers all along the eastern coast are far less considerable than those of the western coast.

We have not the means of deciding how far this great waterparting of Southern Africa continues to form the boundary of the basin of the Nile. It is manifest, however, that in proceeding along it from north to south, we must at length reach a point where the waters on its western side, instead of continuing to flow northwards into the Nile, take their course westwards across the Continent. Consequently, beyond this point the waterparting of Southern Africa is between the hydrographical systems of the Indian Ucean and the Sonthern Atlantic; while at the same time a new waterparting comes into existence between the hydrographical system of the Southern Atlantic, as represented by the river Congo, and that of the Mediterranean, as represented by the Nile; which latter waterparting may, in a general way, be considered to run from east to west, or perhaps rather from south-east to northwest.

In the ordinary maps of Africa we find a chain of mountains laid down as stretching across the Continent from west to east, between the 7 th and 8 th parallels of north latitude. This chain bears the name of the "Mountains of the Moon;" it is supposed to be a continuation of the Kong Mountains of Western Africa, in which the rivers Senegal, Gambia, and Joliba or Niger, have their sources; and on its northern flank the sources of the Nile are also supposed to be situated.

The recent Egyptian expeditions to explore the Nile have, however, demonstrated that such a mountain-chain does not exist; for they have sailed over the alleged site of these "Mountains of the Moon," and have advanced as far as the country of Bari, in the 4th parallel of north latitude, without meeting with 
any mountains that could lay claim to this title. A detailed account of the second of these expeditions, being the one which penetrated the furthest, has recently been published by $\mathbf{M}$. Ferdinand Werne of Berlin, who took part in it*. The author states that, according to Lakono, king of Bari, the course of the river continues thence southwards a distance of thirty days' journey, as far as the country of Anyán, where it divides into four small branches. It may not be easy to determine at what rate this distance of thirty days' journey is to be calculated; but if we roughly estimate it at twelve miles per diem (merely as a first approximation), we shall have a distance of 360 miles, or six degrees of latitude; which distance, measured from Bari, carries us to two degrees south of the equator.

This brings us into the country of Mono-Moézi, of which mention has already been made; and this (coupled with various other circumstances which it is unnecessary to enter on here $\dagger$ ) affords not only a plausible derivation of the name of the "Mountains of the Moon," in which the Nile is, by universal consent, considered to have its origin, but it serves at the same time to determine the position of those mountains in a manner that would seem to be but little, if at all, removed from the truth.

The "Mountains of the Moon" are an established feature of African geography. All writers, whether Arabian or European, mention them; all travellers in central Africa hear of them; and yet so indefinite, so various, so contradictory are the statements respecting these mountains, that nothing in the lenst degree satisfactory has been decided about them. There is however good reason for believing, that all that has been written and said on the subject of the sources of the Nile in the Mountains of the Moon, is founded on the statements of the celebrated astronomer and geographer Claudius Ptolemæus of Alexandria, who flourished in the second century of the Christian æra. One thing is certain, which is, that he is the first writer by whom the Mountains of the Moon are mentioned; and it is most probable that he derived his information respecting them from the Greek traders of Alexandria, who, from the time of Hippalus's discovery of the monsoons in the middle of the preceding century, if not previously, frequented the east coast of Africa.

Our only sure method of proceeding seems, then, to be, that we should refer back to the original statements of Ptolemy; and that, without regarding the numerous commentaries

* Reise zur Entdeckung der Quellen des Weissen Nit. 8vo. Berlin, 1848. $\uparrow$ See Edinburgh New Philosophical Journal, vol. xlv. p. 221 et seq. 
and glosses upon those statements, we should ourselves examine and attempt to elucidate them with the help of the extended geographical knowledge which we possess at the present day.

Now, in the 9th chapter of the 4th book of his Geography, Ptolemy describes the eastern coast of Africa as stretching "towards the east from Cape Rhaptum on the Barbarian Gulf, which is also called the Rough Sea on account of the shoals, as far as Cape Prasum; beyond which the country is unknown." And he proceeds to describe Cape Prasum as being situate in $80^{\circ}$ longitude east of Ferro, and $15^{\circ} \mathrm{S}$. lat.; and that "near it, towards the north-east, is an island, named Menuthius, which lies in $85^{\circ} \mathrm{E}$. long. and $12^{\circ} 30^{\prime} \mathrm{S}$. lat." He adds, that " round the gulf dwell certain cannibal negroes (Athiopes Anthropophagi), on the west of whose country are the Mountains (or hill-country) of the Moon$\tau \grave{o} \tau \hat{\eta} s \Sigma \epsilon \lambda \eta \dot{\eta} \nu$ s ópos-the snows of which are received into the lakes of the Nile." And he describes these Mountains of the Moon as lying in $12^{\circ} 30^{\prime} \mathrm{S}$. lat.; the one extremity of them being in $57^{\circ}$, and the other in $67^{\circ} \mathrm{E}$. long.

On testing, by means of the information possessed by us at the present day, the results arrived at by the geographer of Alexandria, we are at once struck with the great extension in a southerly direction, which Ptolemy has given to the courses of the Nile and its two great tributary streams, the Astaboras and Astapus, as likewise to the eastern coast of Africa, as far as it was then known. For the correction of this fundamental error our means are two. The one is the positive knowledge respecting the courses of the rivers themselves, which has been acquired from the recent Egyptian expeditions up the Nile and the explorations of travellers in Abessinia; the other is the like positive information derived from the surveys made of the east coast of Africa, and from the particulars respecting the interior of the Continent collected at various points along the coast.

From the former of these sources of information we are enabled to lay down, with almost absolute accuracy, the course of the Astaboras, now known as the Atbara or Tákkazie, and that of the Astapus, Blue River or Abái. From the same source we further learn that in about $9^{\circ} \mathrm{N}$. lat. the main stream of the Nile divides into three arms; namely-lst, the Bahr el Abyad or White River, which has been ascended to about the 4th parallel of N. lat.; 2nd, the Sobát, Telfi or River of Habesh, which falls into the central stream from the east, and is considered to contribute to the Nile nearly a moiety of its waters; and 3rd, the Bahr el Ghazál or Keiláh, 
which joins the Nile from the west, and is described as being a magnificent stream, with a tolerably rapid current.

It will be observed, however, that by Ptolemy the main stream of the Nile is laid down as consisting of two principal arms, the junction of which is placed by him in the second parallel of north latitude, or nearly seven degrees to the south of where the junction of the thee principal arms actually takes place. In order to prevent misunderstanding, it is proper to direct attention to the fact, that $I$ am not alluding here to the confluence of the Bahr el Abyad and Bahr el Azrek-the White and Blue Rivers-which are commonly but erroneously called the White and Blue Niles. This confluence takes place at Khartúm in $15^{\circ} 37^{\prime} \mathrm{N}$. lat.; and, as it will be plainly seen, it is merely the junction of the Astapus with the Nilus. Ptolemy's bifurcation of the Nile is, on the contrary, formed by the union of the Sobát, or River of Habesh, with the White River, in $9^{\circ} 20^{\prime} \mathrm{N}$. lat., more than six degrees of latitude to the south of Khartúm. It is important to bear this in mind; as one of the most fertile sources of error in the consideration of this subject, has been the regarding of the Blue River, or "Bruce's Nile" as it is frequently called, as one of the main arms of Ptolemy's Nile, which it manifestly is not.

Turning now to the east coast of Africa, our first point is to identify the island of Menuthias; and though the subject is not altogether free from difficulties, the greatest amount of probability is certainly in favour of the island of Zanzibar. As it is essential to the investigation of the subject that we should advance from some fixed point, it shall be assumed that the identity of Zanzibar with Menuthias is established. And such being the case, it follows that the Barbarian Gulf is the bay or bight in which Zanzibar is situate; and that the country of the Anthropophagi or cannibals dwelling round this gulf, is that portion of the east coast of Africa which is opposite to that island. Further, as the Mountains of the Moon are stated by Ptolemy to lie on the western side of this country of the Anthropophagi, and in the same latitude as Menuthias, we can have no besitation in placing those mountains somewhere in that part of the main land which, in like manner, lies opposite to Zanzibar.

If, now, we apply to these general results the knowledge which we possess of the physical configuration of the plateau of Eastern Africa, of which a brief outline has already been given, we shall perceive that the seaward or eastern edge of this plateau, when viewed from the lowlands along the shores of the Indian Ocean, presents the appearance and indeed possesses the character of an extensive range of lofty moun- 
tains. And that portion of this range which bounds the country of Mono-Moézi, and which lies in a general direction to the west or north-west of the island of Zanzibar, corresponds so satisfactorily with the "Mountains of the Moon," described by Ptolemy as lying on the western side of the country of the Anthropophagi who dwelt on the shores of the Barbarian Gulf near Menuthias, that we may, with every show of reason, consider the identification as absolute, and place here the source of Ptolemy's eastern arm of the Nile.

The name Mono-Moézi itself affords a strong argument in corroboration of this conclusion. This expression is a compound word, significant in many of the languages of the Kafir class, which are spoken throughout the entire continent of Africa south of the Equator, as far as the limits of the Hottentots. The first component of this name, Mono or Mani, is of frequent occurrence in the designations of countries in Southern Africa, such as Mani-Congo, Mani-Puto (as the Portuguese possessions in Africa are called), Mono-Motapa, \&c.; and its meaning appears to be king or ruler. The second component, MoEzi, which alone is properly the name of the country, has the signification of moon in the languages and dialects of the Sawahilis and of the natives of the countries of Mono-Moézi, Congo, Mozambique, and various others. The Sawáhilis, among whom the word is thus significant, are the inhabitants of the sea-coast of Zindj, or Zangebar ; and I conceive that the Greeks of Alexandria who traded with that coast, obtained from these Sawáhilis the particulars respecting the eastern portion of the African continent and the sources of the Nile, which are recorded by their countryman the geographer Ptolemy; and that, as it was not an unusual practice among the Greeks to translate significant proper names into the equivalents in their own language, the designation given by Ptolemy to the mountains in which those sources are situate- $-\sum e \lambda \eta^{\prime} \nu \eta$ s öpos, "the mountains, or hill country, of the moon"-is simply a translation of the Sawáhili expression, "the Mountains of Moézi*."

* The discovery of Mount Kilimandjáro, covered with perpetual snow, recently announced by the Rev. J. Rebmann (see Church Missionary Intelligencer for May 1849, vol. i. p. 17 et seq.), affords an additional argument in support of the above hypothesis. Ptolemy states that "the lakes of the Nile receive the snows of the Mountains of the Moon;" the upper course of the direct stream of the river has been carried southwards to about $2^{\circ} \mathrm{S}$. lat. and $34^{\circ} \mathrm{E}$. long.; and Mount Kilimandjáro, which is crossed by the road from the coast to the country of Mono-Moézi, is placed by $\mathrm{Mr}$. Rebmann in $3^{\circ} 40^{\prime} \mathrm{S}$. lat. and $36^{\circ} \mathrm{E}$. long. Hence the snow-capped Kilimandjaro may be regarded as forming part of the "Mountains of the Moon (Moézi)," in which the Nile has its origin.

Mr. Rebmann mentions that the natives have no specific name for snow, 
It is unnecessary to go into further details to show the reasonableness of the opinion that these "Mountains of the Moon" form the south-eastern rather than the southern limits of the basin of the Nile. As regards the southern limits themselves, no more can be said, in the existing state of our knowledge (or want of knowledge) on the subject, than that they are most probably formed on the east by the basin of the Lutídji or some other large river flowing into the Indian Ocean, and on the west by that of the Upper Congo. It must however not be omitted to be mentioned, that we possess evidence of the existence, somewhere in this direction, of a great lake, which is very incorrectly shown in the ordinary maps under the title of Lake Maravi, and which is more correctly designated Nyassi or "the sea;" an expression apparently equivalent to the Arabic $B a h r$, which is used indefinitely to express a sea, a lake, or a large river, - the "great water," in fact, of Africans generally; but whether this "Nyassi" is connected with the upper course of the Nile, or of the Congo, or of the Lufídji, or whether it possesses a separate hydrographical system of its own, like the Caspian Sea, we have not for the present the means of determining. Should the latter happen to be the case, then it may be the basin of this inland lake, and not those of rivers flowing in opposite directions into the Atlantic and Pacific Oceans, which forms the southern boundary of the river system of the Nile. But however the case may eventually be found to be, the result will not materially affect the arguments already used on the subject; ancl, at all events, some of the north-eastern arms of the Congo will still have their sources at the waterparting between them and the extreme south-western branches of the Nile. It is to be hoped that Dr. Bialloblotzky, who is on his way to explore those regions, will be enabled to clear up some of these dark questions of African geography*.

It only remains for us to consider the western limits of the basin of the Nile; upon which subject an almost total want of positive information precludes us from saying much.

According to the information furnished to $\mathrm{M}$. Werne by Lakono, king of Bari, the direct stream of the Bahr el Abyad, there called 'Tubiri, comes from a distance of thirty days'

which they call coldness. But in this there is nothing singular. In the Arabic and Anbaric languages, bĕrĕd means cold (coldness) generally, while barad (in Amharic more frequently barado) - which is substantially the same-means hail specifically.-July 11, 1849 .

* Since this paper was read this traveller has been compelled to abandon his undertaking. It must now be left to more favoured explorers to perform what was hoped for from him. 
journey to the south. But M. Lafargue, a French traveller who ascended the Bahr el Abyad in 1845, states that he was informed that the main stream comes from the west at a distance of only six days' journey south of Bari. It will be seen that this information is not necessarily opposed to that of M. Werne, since both arms may well exist; but it shows also that we are still in ignorance with respect to an extensive and probably an immense division of the basin of the Nile-namely, the whole of that portion of it which lies to the west of the direct stream ascended by the Egyptian expeditions. In the absence of any certain data, it would be mere speculation to attempt to fix the waterparting in this direction, except that we know that it cannot possibly lie much, if anything, beyond the 20th meridian of east longitude, where the basin of the Nile must necessarily be limited by that of Lake Tchad.

We will therefore descend the main stream of the White River northwards as far as $7^{\circ} 43^{\prime} \mathrm{N}$. lat., where the officers of the second Egyptian expedition found it to receive three branches from the sonth and west. These tributaries were considered to be of no importance, and to appear to proceed only from the neighbouring marshes. But they require to be more closely examined before it can positively be asserted that they are not streams of some, perhaps even considerable importance. Thence continuing to descend the river, we come at length, in $9^{\circ} 20^{\prime} \mathrm{N}$. lat, to the great western arm, called Bahr el Ghazál or Keilláh, which has been already described. The first exploring party was almost in doubt whether this was not the principal arm of the river; but as their instructions from the Pasha were imperative as to their exploring the direct stream, they did not afford it that attention which it evidently deserves. M. Lafargue, who subsequently entered the mouth of this river, describes it as a magnificent stream with a tolerably rapid current.

M. Werne, in speaking of the Bahr el Ghazal, states that it was described to him as coming from Barbary! This our positive knowledge enables us to assert to be impossible. For Denham and Clapperton crossed the continent of Africa from the Mediterranean to Lake 'Tchad, in about the 15 th meridian of east longitude; and we know that there does not exist on their route any watercourse which might be considered as the upper portion of this river. It would, however, doubtless be wrong to understand the expression "Barbary" in the sense in which we usually employ it; as it is not to be imagined that the inhabitants of the valleys of the Bahr el Abyad and Bahr el Ghazál have any actual knowledge of that portion of Africa to which we give this name. We must therefore suppose that, 
in speaking of the origin of the latter river, they made use of some expression equivalent to the Arabic Belád-el Gharb; which, though the name given by Orientals to Barbary, means literally the west country, Barbary being so called simply because it lies to the west of them. Under this view of the case, the statement must be understood to have been, not that this western arm of the Nile rises in Barbary, but merely that it comes from some country in the roest*.

The fact of the existence of this great western arm, which is beyond all question, gives rise to serious considerations. More especially it requires us to re-investigate a statement made by the historian Herodotus respecting the upper course of the Nile-a statement which geographers of modern times have concluded could only be applicable to the Niger, Joliba or Kwara (Quorra) of Western Africa.

In treating, in his second book, of the origin of the Nile, the historian says:- "This river flows from the west and the setting of the sun; but beyond this no one is able to speak with certainty, for the rest of the country is desert by reason of the excessive heat. But $I$ have heard the following account from certain Cyrenæans, who suy that they went to the oracle of Ammon, and had a conversation with Etearchus king of the Ammonians; and that, among other subjects, they happened to discourse about the Nile,- that nobody knew its sources: whereupon Etearchus said, that certain Nasamonians once came to him; this nation is Libyan and inhabits the Syrtis, and the country for no great distance eastward of the Syrtis; and that when these Nasamonians arrived, and were asked if they could give any further information touching the deserts of Libya, they answered, that there were some daring youths amongst them, sons of powerful men; and that they, having reached man's estate, formed many other extravagant plans, and moreover chose five of their number by lot to explore the deserts of Libya, to see if they could make any further discovery than those who had penetrated the furthest. . . . . That when the young men deputed by their companions set out, well-furnished with water and provisions, they passed first through the inhabited country; and having traversed this, they came to the region infested by wild beasts; and after this they crossed the desert, making their way towards the rest; and when they had traversed much sandy ground, during a journey of many days, they at length saw some trees growing in a plain; and that they approached and began to gather the fruit that grew on the trees; and while they were gathering, some diminutive men,

* Algarve, the southernmost province of the kingdom of Portugal opposite Barbary, derives its name from the Arabic el-charb. 
less than men of middle stature, came up, and having seized them carried them away; and that the Nasamonians did not at all understand their language, nor those who carried them off the language of the Nasamonians. However, they conducted them through vast morasses, and when they had passed these, they came to a city, in which all the inhabitants were of the same size as their conductors, and black in colour : and by the city flowed a great river, running from the roest to the east, and that crocodiles were seen in it. Thus far I have set forth the account of Etearchus the Ammonian; to which may be added, as the Cyrenæans assured me, that he said the Nasamonians all returned safe to their own country, and that the men whom they came to were all necromancers. Etearchus also conjectured that this river, which flows by their city, is the Nile; and reason so evinces: for the Nile flows from Libya, and intersects it in the middle, and (as I conjecture, inferring things unknown from things known) it sets out from a point corresponding with the Ister. . . . . So I think that the Nile, traversing the whole of Libya, may be properly compared with the Ister. Such, then, is the account that I am able to give respecting the Nile*."

The objection usually made to the supposition that this river of Herodotus is the upper course of the Nile, is, that the Nasamonians travelled, not southwards but westwards, and that consequently they could not have reached any river but the Niger. But, if the historian's expressions are to be taken as strictly meaning that the road lay throughout in a westerly direction, it is manifest that it would be just as impossible for the travellers to have arrived at the Niger as to have reached a western arm of the river of Egypt. In either case, then, we are bound to suppose that they first proceeded southwards - to what distance we cannot say - and then, by con. tinuing during the last part of their journey in a westerly direction (which is in no wise to be understood as meaning due west), they may without difficulty bave come to the Nile, that is to say, to the upper course of this great western arm, possibly at no very great distance to the east or north-east of Lake Tchad.

The mention of this lake induces me to suggest the probability that Nyassi and Tchad, the one at the extremity of the southernmost and the other at the extremity of the westernmost arm of the Nile, are the originals of the two lakes which Ptolemy describes as receiving the snows of the Mountains of the Moon.

It has merely to be added, that, according to a sketch-map * Lib. ii. \$ 31-34; Cary's translation.

Phil. Mag. S. 3. Vol. 35. No. 234. Aug. 1849. 
of Darfúr, drawn at Cairo in 1841 by Dr. Perron, under the dictation of Sheikh Mohammed el Túnisi, there is a large river in the west of that country named Bare; and that from the evidence collected by M. Jomard in his Preface to the Voyage au Darfour of the Sheikh, it may be concluded that both that country and Kordofán lie within the basin of the Nile, and that this river Bare is an affluent of the Bahr el Ghazál of the Egyptian expeditions.

We have thus brought the limits of the hydrographical system of the Nile round again to the confines of Nubia and Egypt; in which countries, as it is well known, the basin of that river, on the western as on the eastern side, consists of little more than the bed of the stream itself.

St. Mildred's Court,

Dec. $30,1848$.

XV. On the Effect of surrounding Media on Voltaic Ignition. By W. R. Grove, Esq., M.A., V.P.R.S.*

TN the Philosophical Magazine for December 1845, I 1 pointed out a striking difference between the heat generated in a platinum wire by a voltaic current, according as the wire is immersed in atmospheric air or in hydrogen gas, and in the Bakerian Lecture for 1847 I have given some further experiments on this subject, in which the wire was ignited in atmospheres of various gases, while a voltameter enclosed in the circuit yielded an anount of gas in some inverse ratio to the heat developed in the wire. It was also shown, by a thermometer placed at a given distance, that the radiated heat was in a direct ratio with the visible heat.

Although the phænomenon was apparently abnormal, there were many known physical agencies by which it might possibly be explained, such as the different specific heats of the surrounding media, their different conducting powers for electricity, or the varying fluency or mobility of their particles which would carry off the heat by molecular currents with different degrees of rapidity.

The investigation of these questions will form the subject of this paper.

An apparatus was arranged, see fig. 1. Two glass tubes $\mathbf{A}$ and $B$, of 0.3 inch internal diameter and 1.5 inch length, were closed with corks at each extremity; through the corks the ends of copper wires penetrated, and joining these were coils of fine

* From the Philosophical Transactions for 1849 , part $i$; having been received by the Royal Society August 10, and read December 14, 1848. 